\title{
Vps10 Family Proteins and the Retromer Complex in Aging-Related Neurodegeneration and Diabetes
}

\author{
Rachel F. Lane, ${ }^{1}$ Peter St George-Hyslop, ${ }^{2,3}$ Barbara L. Hempstead, ${ }^{4}$ Scott A. Small, ${ }^{5}$ Stephen M. Strittmatter, ${ }^{6}$ and \\ Sam Gandy 7,8 \\ ${ }^{1}$ Alzheimer's Drug Discovery Foundation, New York, New York 10019, ${ }^{2}$ Tanz Centre for Research in Neurodegenerative Diseases, University of Toronto, \\ Toronto, ON M5S 3H2 Canada, ${ }^{3}$ Cambridge Institute for Medical Research and Department of Clinical Neurosciences, University of Cambridge, Cambridge \\ CB2 0XY, United Kingdom, ${ }^{4}$ Department of Medicine, Weill Cornell Medical College, New York, New York 10065, ${ }^{5}$ Department of Neurology and the Taub \\ Institute, Columbia University, School of Physicians and Surgeons, New York, New York 10032, ${ }^{6}$ Cellular Neuroscience, Neurodegeneration and Repair \\ Program, Departments of Neurology and Neurobiology, Yale University School of Medicine, New Haven, Connecticut 06536, ${ }^{7}$ Departments of Neurology \\ and Psychiatry and the Alzheimer's Disease Research Center, Mount Sinai School of Medicine, New York New York 10029, and ${ }^{8}$ James J. Peters Veterans \\ Affairs Medical Center, Bronx, New York 10468
}

Members of the vacuolar protein sorting 10 (Vps10) family of receptors (including sortilin, SorL1, SorCS1, SorCS2, and SorCS3) play pleiotropic functions in protein trafficking and intracellular and intercellular signaling in neuronal and non-neuronal cells. Interactions have been documented between Vps10 family members and the retromer coat complex, a key component of the intracellular trafficking apparatus that sorts cargo from the early endosome to the trans-Golgi network. In recent years, genes encoding several members of the Vps10 family of proteins, as well as components of the retromer coat complex, have been implicated as genetic risk factors for sporadic and autosomal dominant forms of neurodegenerative diseases, including Alzheimer's disease, frontotemporal lobar degeneration, and Parkinson's disease, with risk for type 2 diabetes mellitus and atherosclerosis. In addition to their functions in protein trafficking, the Vps10 family proteins modulate neurotrophic signaling pathways. Sortilin can impact the intracellular response to brain-derived neurotrophic factor (BDNF) by regulating anterograde trafficking of Trk receptors to the synapse and direct control of BDNF levels, while both sortilin and SorCS2 function as cell surface receptors to mediate acute responses to proneurotrophins. This mini-review and symposium will highlight the emerging data from this rapidly growing area of research implicating the Vps10 family of receptors and the retromer in physiological intracellular trafficking signaling by neurotrophins and in the pathogenesis of neurodegeneration.

\section{Introduction}

A number of neurodegenerative diseases including Alzheimer's disease (AD), Parkinson's disease (PD) and frontotemporal lobar degeneration (FTLD, or, simply FTD) are characterized by the misprocessing and missorting of intracellular proteins [amyloid precursor protein (APP), $\alpha$-synuclein, tau] within endosomallysosomal pathways. Dysfunction within these pathways is proposed to be a major contributing factor to disease progression. Recently, a number of genome-wide association studies (GWAS) and biochemical studies have identified members of the vacuolar protein sorting-10 (Vps10) family of receptors (including SORT1, SORL1, SORCS1, SORCS2 and SORCS3) and core com-

Received July 13, 2012; revised Sept. 4, 2012; accepted Sept. 6, 2012.

We gratefully acknowledge the support of the NIH (NS075685 to S.G., NS030687 to B.L.H., AG025161 to S.A.S., NS074319 and AG034924 to S.M.S.), the Wellcome Trust, Canadian Institutes of Health Research, Alzheimer Society of Ontario, and Howard Hughes Medical Institute (P.StG.-H.), the Cure Alzheimer's Fund (S.G.), and the US Department of Veteran Affairs (S.G.). R.F.L. and S.G. thank Dr. Alan Attie for providing advice and helpful conversations during the preparation of this paper.

Correspondence should be addressed to either of the following: Rachel F. Lane, Alzheimer's Drug Discovery Foundation, 57 W 57th Street, Suite 904, New York, NY, 10019, E-mail: RLane@alzdiscovery.org, or Sam Gandy, Departments of Neurology and Psychiatry and the Alzheimer's Disease Research Center, Mount Sinai School of Medicine, One Gustave L. Levy Place, New York NY 10029, E-mail: samuel.gandy@mssm.edu.

DOI:10.1523/JNEUROSCI.3359-12.2012

Copyright $\odot 2012$ the authors $\quad 0270-6474 / 12 / 3214080-07 \$ 15.00 / 0$ ponents of the retromer (VPS35 and VPS26) that regulate endosomal sorting as risk factors for neurodegenerative diseases. SORL1, SORCS1 and VPS35 have been linked to AD (Small et al., 2005; Rogaeva et al., 2007; Liang et al., 2009; Lane et al., 2010; Willnow et al., 2010; Reitz et al., 2011c;), VPS35 has additionally been linked to PD (Vilariño-Güell et al., 2011; Zimprich et al., 2011), and SORT1 (sortilin) has been linked to FTD (Carrasquillo et al., 2010; Hu et al., 2010). Interestingly, SORCS1 and VPS26a have also been linked to type 2 diabetes mellitus (T2DM) (Goodarzi et al., 2007; Kooner et al., 2011) and SORT1 has been linked to cardiovascular disease (CVD) (Musunuru et al., 2010), both independent risk factors for late-onset $\mathrm{AD}$. In addition to their regulation of retrograde trafficking, the Vps10 family members have been implicated in neurotrophin signaling through anterograde trafficking of Trk receptors (Vaegter et al., 2011), the primary receptors for brain-derived neurotrophic factor (BDNF) signaling as well as in regulation of BDNF levels (Chen et al., 2005; Evans et al., 2011) and proneurotrophin signaling (Deinhardt et al., 2011).

The VPS10 receptor family also interacts with APOE (APOE gene; apoE, protein), a well characterized risk factor for late-onset $\mathrm{AD}$ (LOAD) and CVD. SorL1 was first identified as a receptor for apoE in the brain and has subsequently, together with sortilin, been implicated in systemic lipoprotein metabolism and as risk factors for CVD (for review, see Willnow et al., 2011). GWAS 


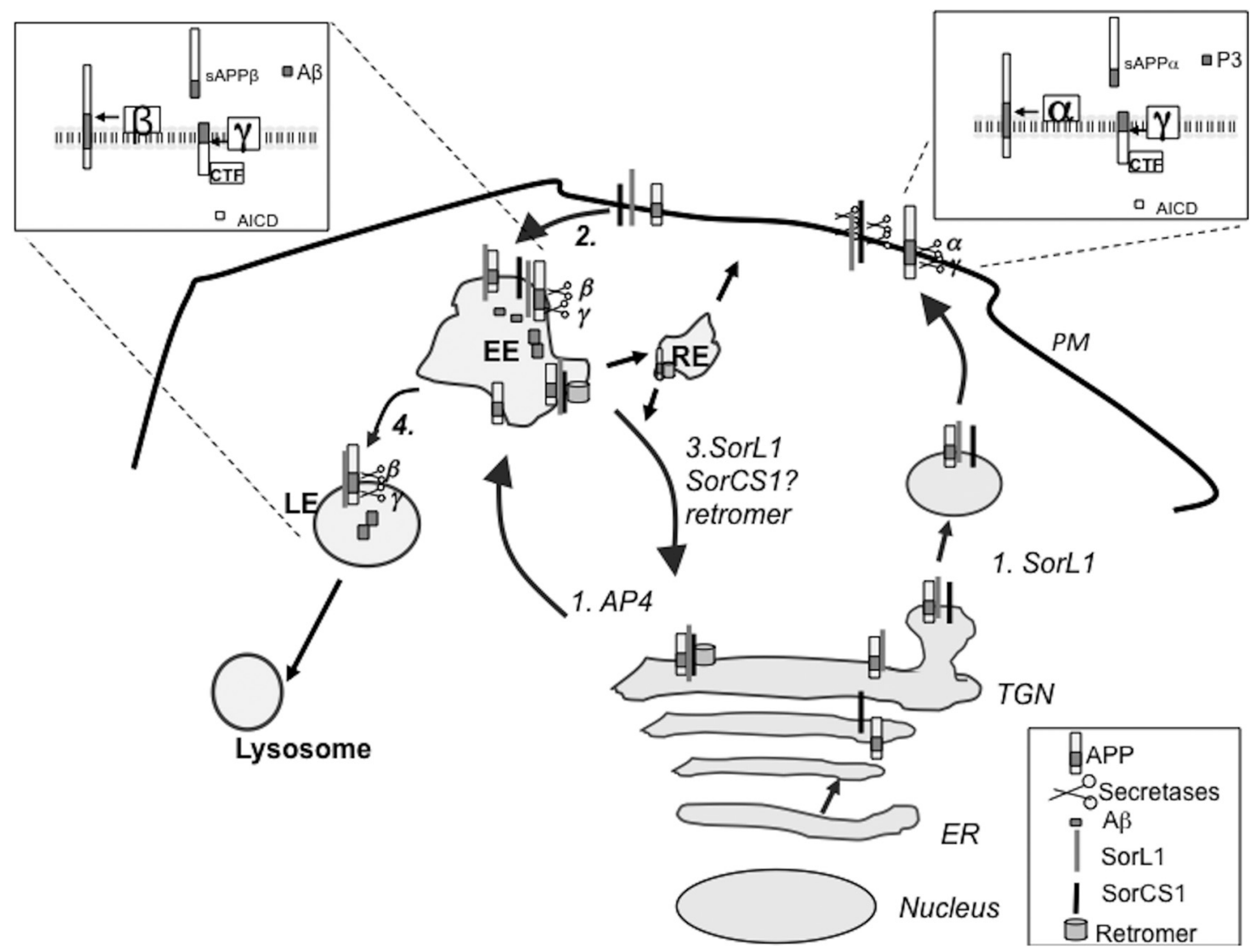

Figure 1. APP trafficking and processing. 1, Upon exit from the TGN, APP is sorted into either constitutive secretory vesicles to the plasma membrane or into clathrin-coated vesicles into the endosomal pathway dependent on AP4. Within the secretory pathway and primarily at the plasma membrane (PM), APP is cleaved by the $\alpha$-secretases (ADAM10, ADAM17) into the soluble APP $\alpha$ $(\operatorname{sAPP} \alpha)$ fragment and a membrane-bound $\alpha$ CTF. The $\alpha$ CTF is subsequently cleaved by the $\gamma$-secretase machinery resulting in generation of the p3 fragment and the APP intracellular domain (AICD). 2, Following residence at the PM, some unprocessed APP escapes $\alpha$-secretase cleavage and is internalized into the endosomal pathway. Within low pH endosomal compartments, APP is cleaved by BACE, resulting in generation of SAPP $\beta$ and the $\beta$ CTF. Cleavage of the $\beta$ CTF by $\gamma$-secretase occurs initially at the $\varepsilon$-site. This is subsequently followed by additional C-terminal cleavage events to the $\gamma$-secretase site (N terminal to the $\varepsilon$-site) resulting in formation of the A $\beta$ peptide (of varying lengths) and the AICD. 3, 4, APP is recycled from the early endosomal compartments [early endosomes (EE), late endosomes (LE), recycling endosomes (RE)] to the TGN via the retromer complex and its receptors, the Vps 10 family members. To date, SorL 1 has been shown to regulate APP exit from EE and sorting from EE to the TGN via an interaction with core components of the retromer. While the retromer has been additionally implicated in retrograde trafficking between recycling endosomes and the TGN, direct evidence has not yet been provided for this compartment in retromer regulation of APP trafficking. Evidence suggests SorCS1 trafficking within endosomal compartments is dependent on SorL1 and the retromer (4).

support the interaction of APOE and VPS10 family members in risk for $\mathrm{AD}$ and $\mathrm{CVD}$, in part based on data suggesting that SORCS1 and APOE interact in the development of AD (Wang et al., 2012). SORCS1 was also highlighted in GWAS for T2DM (Goodarzi et al., 2007) as was the retromer component, Vps26a (Kooner et al., 2011). CVD and T2DM are established risk factors for LOAD, and elucidation of the biology of Vps10 family of receptors may shed light on molecular mechanisms linking these common systemic metabolic diseases with equally common neurodegenerative diseases. Since much of the attention recently drawn to this family of proteins has resulted from their linkage to neurological diseases, we will begin this mini-review and symposium with highlights of Vps10 family-based and retromer-based pathogenesis before turning to a discussion of their normal physiological actions in intracellular sorting pathways, including their contribution to proneurotrophin signaling pathways, apoptosis, and acute retraction of neuronal processes in response to stress.

\section{The roles of the Vps10 receptors in neurodegenerative diseases}

Overwhelming evidence points to endosomes as the primary compartment for misprocessing of APP and for the production of amyloid $\beta(\mathrm{A} \beta)$. The acidic nature of the endosomal compartments promotes production and aggregation of $\mathrm{A} \beta$ (for review, see Small and Gandy, 2006), and dysfunction within the endosomal pathway is implicated early in disease progression (Cataldo et al., 1997, 2000, 2004). Activity of BACE1, the $\beta$-site APP cleavage enzyme, is optimized within acidic environments and is the initial APP cleavage event in the amyloidogenic cascade that results in the production of A $\beta$ (Fig. 1; for review, see Small and Gandy, 2006). Proteins that modulate internalization of APP and APP C-terminal fragments (CTFs) into and between endosomal compartments and from endosome to lysosome remain to be fully characterized. In the last few years, however, in the last few years, a number of studies have provided evidence that disruption in endosome to trans-Golgi network (TGN) trafficking contributes to the formation of toxic protein species, often involving molecules of the Vps10 receptor family. Since several of these pathways converge on the retromer coat complex, we will begin with a review of that macromolecular assembly.

The retromer coat complex

The retromer is a coat complex that regulates retrograde sorting from the endosome to TGN (for review, see Small, 2008). The 
retromer was first identified in yeast as a trafficking complex required for recycling of $\mathrm{Vps} 10$, a molecule required for efficient function of the yeast vacuole, from the endosomal-lysosomal pathway to the TGN. This pathway is analogous to sorting of the mannose 6 phosphate receptor in mammalian systems (for review, see Small, 2008; Burd, 2011). Retromer coat complexes are macromolecular assemblies, consisting of two subcomplexes: the Vps subunit (Vps26a or Vps26b, Vps35, Vps29) and a dimer of sorting nexins (SNX), including combinations of SNX 1, 2, 5, or 6 (Bonifacino and Hurley, 2008). The Vps subunit of the retromer plays a role in cargo specificity, with Vps26a and Vps26b subunits demonstrated to play regulatory roles in this selection, while the SNX complex provides a structural role, tubulating and recruiting the Vps subunits to early endosomal membranes (Bonifacino and Hurley, 2008).

The retromer was first linked to LOAD by model guided microarray analysis of the dentate gyrus and entorhinal cortex from AD tissue (Small et al., 2005). Reduced protein levels of the core retromer components, Vps35 and Vps26, were identified within regions of the brain that are selectively vulnerable to $\mathrm{AD}$ (Small et al., 2005). Most recently, $S N X 1, S N X 3$, and RAB7A, essential for membrane association of the retromer, were also identified as possible AD risk genes (Vardarajan et al., 2012). Interestingly, autosomal dominant mutations in VPS35 are also causative of a late-onset form of PD (Vilariño-Güell et al., 2011; Zimprich et al., 2011). Some in vitro and in vivo models demonstrate that the retromer negatively regulates $\mathrm{A} \beta$ production, with Vps35deficient mice exhibiting increased $\mathrm{A} \beta 40$ and $\mathrm{A} \beta 42$ production (Muhammad et al., 2008). However, in other models, some investigators have demonstrated that retrograde trafficking is required for efficient $A \beta 40$ production (Sullivan et al., 2011; Choy et al., 2012). Interestingly, Sullivan et al. (2011) also demonstrated increased secretion of APP CTFs via exosomes, suggesting that retromer deficiency might redirect trafficking of APP CTFs into exosomes, providing a previously unknown, alternative pathway for secretion of APP fragments. Conceivably, exosomesecreted APP CTFs could be a source of extracellular A $\beta$. Further investigation is required to determine the relative contribution of exosomal APP fragment release to $\mathrm{A} \beta$ production and to address what appear to be contradictory data on the effects of retromer deficiency that are observed in different model systems.

The Vps10 receptor family

The Vps 10 receptor family members are typical type 1 transmembrane proteins, characterized by a Vps10 homology domain within their $\mathrm{N}$ terminus that represents a site for ligand binding. While the Vps10 receptor family members are characterized by canonical internalization and sorting motifs within their cytoplasmic tails that mediate rapid internalization and intracellular sorting of ligands (Jacobsen et al., 2001; Nielsen et al., 2001), these molecules are also implicated in proneurotophin signaling pathways. They are abundantly expressed in the developing brain; they show differential distribution within hippocampal structures; and they are induced by neuronal activity (Hermey et al., 2001, 2004).

SorL1. SORL1 was the first member of the family of Vps10 proteins to be genetically linked with LOAD (Rogaeva et al., 2007), and SORL1 mutations have now also been suggested as causes of familial AD (Pottier et al., 2012). Numerous studies have replicated the association of SORL1 with AD in different datasets, and a recent comprehensive meta-analysis confirmed that multiple SORL1 variants are associated with AD risk (Reitz et al., 2011a). Furthermore, this analysis demonstrated that several
SORL1 single nucleotide polymorphisms (SNPs) are associated with $\mathrm{AD}$ endophenotypes including white matter hyperintensity, hippocampal atrophy, CSF A $\beta 42$ levels, and SORL1 expression in the brain (Reitz et al., 2011a). SORL1 transcripts are decreased in the brains of patients with mild cognitive impairment (Sager et al., 2007) and AD (Dodson et al., 2006), and a synthesis of the possible roles of Vps35 and SorL1 in AD pathogenesis led to the proposal that Sorl1 might link APP to the retromer coat complex (Small et al., 2005; Small and Gandy, 2006). Subsequent in vitro and in vivo studies have now shown that SorL1 is indeed required for endosome to TGN trafficking of APP (Vieira et al., 2010; Fjorback et al., 2012). Disruption of the Vps26 binding motif within the SorL1 cytoplasmic tail results in increased localization of APP to endosomal compartments and increased amyloidogenic processing of APP to produce A $\beta$ (Fjorback et al., 2012). One should note that this might or might not be the sole site for intracellular regulation of APP metabolism by SorL1. SorL1 has also been demonstrated to regulate exit of APP from the TGN (Schmidt et al., 2007), exit of APP from early endosomal compartments (Offe et al., 2006), and oligomerization of APP which regulates its affinity for the secretases (Lao et al., 2012; Schmidt et al., 2012).

While evidence suggests that disruption of the retromer and the retromer-SorL1 interaction impacts APP metabolism and A $\beta$ production in several in vitro and in vivo models (Muhammad et al., 2008; Vieira et al., 2010; Fjorback et al., 2012), the role of the retromer in long-distance trafficking of APP within neuronal processes was, until recently, relatively uncharacterized. Using cultured hippocampal neurons, Small and colleagues (Bhalla et al., 2012) have demonstrated that the core retromer components, Vps35 and Vps26, partially colocalize with SorL1 and APP to distinct puncta that are positive for early endosome markers and are localized within neuronal processes.

Investigation into the kinetics of Vps35- and APP-positive vesicles in hippocampal neurons have demonstrated that, like other polarized cell models, the neuronal retromer, while not present within long-range moving vesicles, is nonetheless required for long-range retrograde transport of APP I-containing vesicles (Bhalla et al., 2012). Under Vps35 knockdown conditions, APP long-range transport was reduced, resulting in a more static behavior of APP-positive vesicles, indicating that Vps35 may also be required for the regulated exit of APP from early endosomes in distal processes. This block of APP exit from early endosomes paralleled an increase in endosomal size and $\mathrm{A} \beta$ production (Bhalla et al., 2012), potentially consistent with previous observations of enlarged endosomes during the earliest stages of AD before amyloid deposition (Cataldo et al., 1997, 2000, 2004) and in patient derived stem cells (Qiang et al., 2011; Israel et al., 2012). Together, these studies suggest that retromer dysfunction leads to increase clustering of APP in early endosomes (more so in distal processes than in the soma) thereby contributing to $\mathrm{A} \beta$ generation.

SorCS1. A second member of the Vps10 family, SORCS1, was additionally identified as a potential risk factor for LOAD (Liang et al., 2009), and recent independent studies from the Gandy and Mayeux labs have highlighted a role for SorCS1 in regulation of APP metabolism and A $\beta$ generation (Lane et al., 2010; Reitz et al., 2011c). Initial studies by Lane et al. (2010) described a role for SorCS1 in the regulation of $A \beta$ generation and implicated the retromer in this regulation. Complexes containing SorCS1, APP, Vps35 and SorL1 were isolated from mouse brain tissue, and Vps35 and SorL1 protein levels were reduced in the brains of Sorcs1-deficient mice, suggesting disruption of the retromer in 
the absence of SorCS1. Analysis of APP metabolites and A $\beta$ in the brains of female Sorcs 1-deficient mice revealed increased processing of endogenous APP as shown by elevated levels of $\alpha / \beta$ CTF and $\mathrm{A} \beta$ production (Lane et al., 2010). The sexual dimorphism observed in APP metabolism parallels genetic data showing that the SORCS1 linkage to both $\mathrm{AD}$ and $\mathrm{T} 2 \mathrm{DM}$ is stronger for females (Liang et al., 2009). Mayeux and colleagues subsequently reported genetic association of 16 SORCS1 SNPs with LOAD (Reitz et al., 2011c) and identified variations in intron 1 of SORCS1 to be associated with changes in memory retention in the National Institute on Aging-LOAD dataset (Reitz et al., 2011b). Reitz et al. (2011) confirmed the original observations of Lane et al. (2010), in the demonstration that, in cultured cells, SorCS1 interacts with APP and regulates A $\beta$ generation. Reitz et al. (2011c) went on to suggest $\gamma$-secretase as the point of SorCS1 action on $\mathrm{A} \beta$ generation.

Interestingly, SORCS1, was first identified as the quantitative trait locus for T2DM in rats and mice (Clee et al., 2006; Granhall et al., 2006) and was subsequently identified in GWAS as a risk factor for type 1 diabetes (Paterson et al., 2010) and T2DM (Goodarzi et al., 2007). Epidemiological studies demonstrate an association between T2DM and AD (Ott et al., 1996). While the mechanism through which SORCS1 contributes to T2DM remains uncharacterized, the interaction with the retromer provides a potential point of convergence between $\mathrm{AD}$ and T2DM, not only for SorCS1 but also for other Vps10 receptors including sortilin and SorL1. The role for sortilin has been well described in regulation of trafficking of Glut4-containing, insulin-responsive vesicles (IRVs), and a screen to identify additional components of IRVs identified both SorL1 and Vps35 in rat adipocytes (Jedrychowski et al., 2010). Recycling of Glut4-containing IRVs from endosomal compartments to the TGN is dependent on retrograde trafficking pathways and is essential for correct Glut4 trafficking in response to insulin (Vassilopoulos et al., 2009). Genetic data now also point toward the retromer in T2DM with VPS26a recently identified as a novel susceptibility locus (Chambers et al., 2011). Together, these data point toward the retromer as a potential point of convergence between the two diseases.

Sortilin. Sortilin, a third member of the Vps10 family of receptors, has been implicated in FTD (Hu et al., 2010), CVD (Musunuru et al., 2010), and several psychiatric disorders including depression and bipolar disorder (Dubé et al., 2011; Nykjaer and Willnow, 2012). Sortilin is implicated as a major risk factor for CVD (Musunuru et al., 2010). However, the role of sortilin in CVD pathogenesis, and vice versa, remains to be elucidated in detail. Sortilin has also been implicated in intracellular sorting of BACE1. In vitro, sortilin interacts with BACE1 and appears to positively regulate BACE1 cleavage of $\mathrm{APP}$ and $\mathrm{A} \beta$ production. Deletion of the sortilin intracellular domain, containing the putative retromer binding domain, resulted in increased endosomal localization of sortilin and BACE1 (Finan et al., 2011). While the impact on $A \beta$ production was not assessed, these data appear to conflict with the model for negative regulation of $\mathrm{A} \beta$ production via the SorL1-retromer interaction. In the $\mathrm{AD}$ brain, increased sortilin expression (Finan et al., 2011), together with a positive correlation between temporal cortex sortilin levels and severity of pathology has been reported (Mufson et al., 2010).

Recently, an additional role for sortilin has been described in the pathogenesis of FTD. Haploinsufficiency of progranulin is a common genetic cause of FTD with TDP-43 aggregates (FTDTDP). Expression cloning of cell surface progranulin binding sites identified sortilin as a receptor for progranulin in neurons

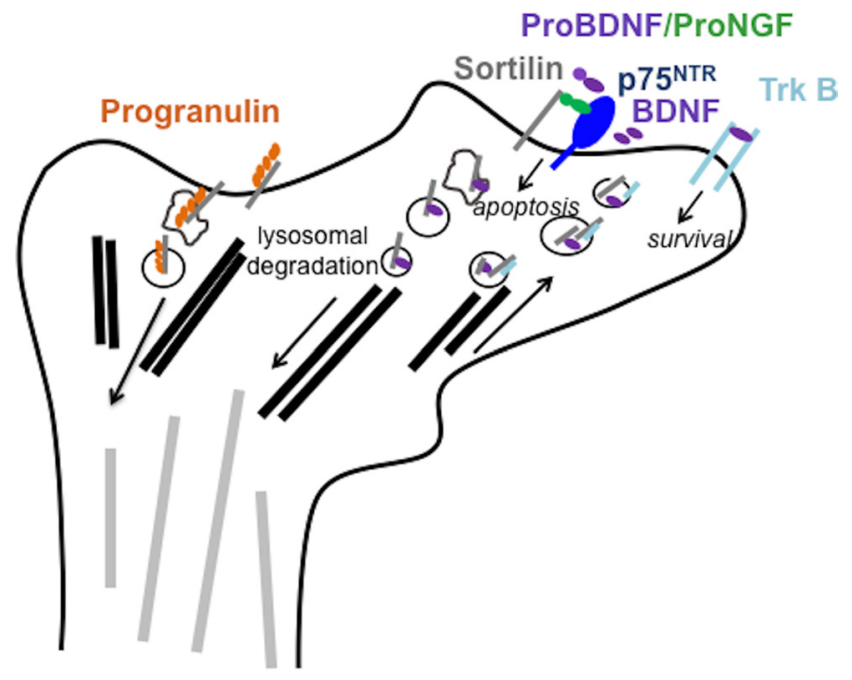

Figure 2. Model of sortilin function in trafficking of neurotrophins and Trk receptors. Sortilin (gray bar) functions as a coreceptor for the p75NTR receptor (blue) in proneurotrophin signaling pathways. In addition to a role in proneurotrophin signaling, sortilin functions as a trafficking receptor for both Trk receptors and BDNF through the secretory pathway. In BDNF trafficking, the soluble sortilin ectodomain, cleaved of its intracellular sorting signals in the cytoplasmic tail (not membrane associated), rescues BDNF from lysosomal degradation pathways and redirects BDNF through the secretory pathways. Holo sortilin, however, has been demonstrated to mediate BDNF endocytosis and targeting to the lysosome for degradation. Another ligand, progranulin (orange), is targeted to the endosomal-lysosomal pathway through a sortilindependent mechanism.

(Hu et al., 2010). Independently, GWAS identified SORT1 as a regulator of plasma progranulin levels (Carrasquillo et al., 2010). Progranulin was demonstrated to localize extensively with sortilin at the plasma membrane with binding dependent on the sortilin $\beta$-propeller domain ( $\mathrm{Hu}$ et al., 2010). In vitro and in vivo models demonstrate that sortilin regulates extracellular progranulin levels through endocytosis and lysosomal accumulation of progranulin (Hu et al., 2010; Fig. 2). Deletion of sortilin results in a 2.5- to 5-fold increase in progranulin levels and reversal of progranulin deficiency in the GRN ${ }^{+/-}$FTD model. Together, these data highlight a role for sortilin in the uptake and targeted delivery of progranulin to the endosomal-lysosomal pathway at levels relevant to the clinical disease (Hu et al., 2010).

The roles of specific Vps10 receptors in proneurotrophin signaling pathways

Sortilin. In addition to the roles highlighted here for the Vps10 family of receptors in protein trafficking of ligands linked to several neurodegenerative diseases and to T2DM, several members of this family are implicated as cell surface receptors that regulate proneurotrophin signaling. To date, the neurotrophin (NT) family members, consisting of nerve growth factor (NGF), BDNF, neurotrophin 3 (NT3) and neurotrophin 4 (NT4), are known to signal through two complexes: $775^{\mathrm{NTR}_{-}}$sortilin and the $\mathrm{p} 75^{\mathrm{NTR}}$ Trk receptor complexes (for review, see Teng et al., 2010). Neurotrophins including NGF and BDNF are synthesized as precursor proteins (proneurotrophins) that are cleaved of their prodomains during maturation. However, following injury, or in neurodegenerative disease, pro-NGF is induced. Numerous studies have indicated that pro-NTs (NGF and BDNF) bind the p75 ${ }^{\text {NTR }}$-sortilin complex to signal proapoptotic pathways while mature NTs bind the Trk receptor complexes to signal growth cone tuning, extension, and neuronal survival (for review, see Teng et al., 2010). While sortilin functions directly in apoptotic signaling pathways when complexed with $\mathrm{p} 75^{\mathrm{NTR}}$, sortilin has 
also been implicated in anterograde trafficking of the Trk receptors from the soma to the nerve terminal, thereby positively regulating neurotrophin signaling and cell survival (Vaegter et al., 2011), regulation of BDNF levels through regulating both anterograde and lysosomal trafficking (Chen et al., 2005; Evans et al., 2011; Fig. 2).

Disruptions in NGF and BDNF signaling have been demonstrated to contribute to $\mathrm{AD}$ pathology. Aberrant processing of pro-NGF and/or altered axonal trafficking resulting in an imbalance of pro-NGF to mature NGF has been implicated in disease progression and decreased $\mathrm{BDNF}$ has been reported in $\mathrm{AD}$. However, the fact that no NT or NT receptor has been genetically linked to any neurodegenerative disorder means that no primary cause-effect relationship has been defined in human disease pathogenesis. In addition to implications in neurodegeneration, pro-NGF and p75NTR are acutely increased following acute axonal and spinal cord injuries that result in acute degeneration of neuronal projections (for review, see Teng et al., 2010).

SorCS2. Most recently, a role for a fourth member of the Vps10 family of receptors, SorCS2, was identified as a receptor that binds to pro-NGF, thereby mediating acute collapse of growth cones of hippocampal neurons (Deinhardt et al., 2011). In E18 primary hippocampal neurons, Hempstead and colleagues (Deinhardt et al., 2011) demonstrated that pro-NGF induced rapid growth cone collapse of neurons expressing endogenous-p $75^{\mathrm{NTR}}$, but not sortilin. Through a proteomics approach, Deinhardt et al. (2011) identified the scaffold RacGTPase exchange factor (GEF) protein, Trio, as an intracellular protein that binds to the SorCS2-p75 ${ }^{\text {NTR }}$ complex. They went on to show that pro-NGF can induce displacement of Trio from the SorCS2-p75 ${ }^{\text {NTR }}$ complex. Displacement of Trio resulted in local inactivation of Rac and subsequent growth cone collapse. In addition, the authors identified fascin, an actin binding protein that regulates the formation of stable actin bundles and is negatively regulated by a PKC phosphorylation event, as a second interacting protein that mediates growth cone collapse. Pro-NGF induces PKC activation, phosphorylation of fascin, and retraction of actin filaments (Deinhardt et al., 2011; Fig. 3). Collectively, these results suggest dual synchronized mechanisms by which pro-NGF mediates acute neuronal remodeling. This increase in $\mathrm{p} 75^{\mathrm{NTR}}$ in injured neurons, and the increase in pro-NGF in AD suggests that SorCS2/ $\mathrm{p} 75^{\mathrm{NTR}}$ may play a role in disease pathogenesis.

\section{Conclusions}

Data from multiple genetic and cell biology studies indicate that proteins involved in intracellular trafficking play critical roles in the generation of toxic protein species common to a number of neurodegenerative diseases. Importantly, while a number of studies now also correlate these genetic and cell biology studies with disease endophenotypes, including white matter hyperintensity, hippocampal atrophy, and memory retention (Reitz et al., 2011a,b) confirmation of the pathogenic nature of SNPs identified from GWAS analysis is required. Evidence suggests that the Vps10 family of receptors regulate trafficking of proteins central to several neurodegenerative diseases within endosomallysosomal compartments through their interaction with the retromer complex (itself implicated in AD, PD, and T2DM). Importantly several of the Vps10 family additionally regulate neurotrophic survival and apoptotic signaling pathways. In considering these molecules as targets for drug discovery, the "druggability" of these pathways is complicated by this intricate balance of functions. However, further research into this evolving

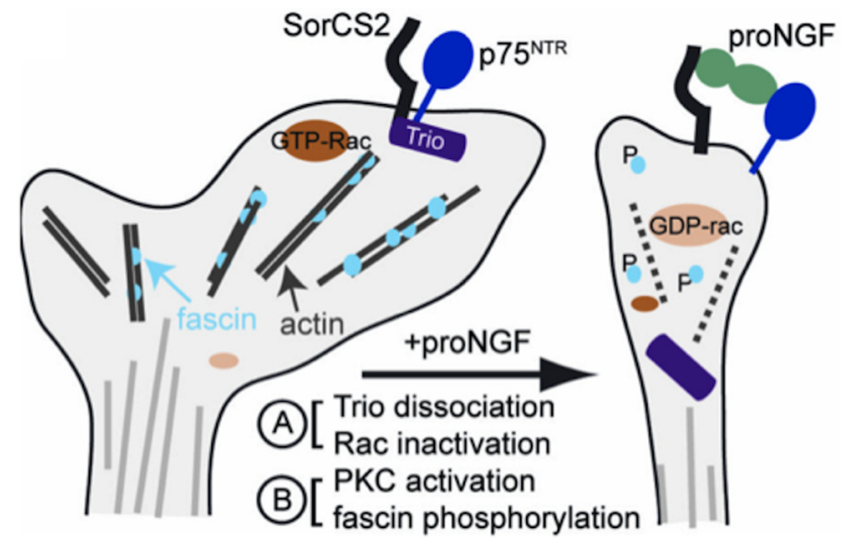

Figure 3. Model of acute pro-NGF action of SorCS2-dependent growth cone collapse. The Rac GEF, Trio, positively regulates Rac activity when bound to the SorCS2-p75 NTR receptor complex in expanding growth cones (dark orange ovals, active Rac). Following pro-NGF binding, the Rac GEF, Trio, is displaced from the SorCS2-p75 ${ }^{\text {NTR }}$ receptor complex resulting in loss of Rac activity (light orange ovals) and impaired filopodial formation. In parallel, PKC activation and phosphorylation of fascin, the actin-bundling protein (blue circles), results in dissociation of fascin from actin filaments, loss of actin organization, and growth cone collapse. Figure reproduced from Deinhardt et al., 2011, with permission of the AAAS and Science magazine.

field has the potential to identify common targets for therapeutic intervention with utility in a number of indications including the most common neurological, cardiovascular, and metabolic diseases.

\section{References}

Bhalla A, Vetanovetz CP, Morel E, Chamoun Z, Di Paolo G, Small SA (2012) The location and trafficking routes of the neuronal retromer and its role in amyloid precursor protein transport. Neurobiol Dis 47:126-134. CrossRef Medline

Bonifacino JS, Hurley JH (2008) Retromer. Curr Opin Cell Biol 20:427436. CrossRef Medline

Burd CG (2011) Physiology and pathology of endosome-to-Golgi retrograde sorting. Traffic 12:948-955. CrossRef Medline

Carrasquillo MM, Nicholson AM, Finch N, Gibbs JR, Baker M, Rutherford NJ, Hunter TA, DeJesus-Hernandez M, Bisceglio GD, Mackenzie IR, Singleton A, Cookson MR, Crook JE, Dillman A, Hernandez D, Petersen RC, Graff-Radford NR, Younkin SG, Rademakers R (2010) Genome-wide screen identifies rs646776 near sortilin as a regulator of progranulin levels in human plasma. Am J Hum Genet 87:890-897. CrossRef Medline

Cataldo AM, Barnett JL, Pieroni C, Nixon RA (1997) Increased neuronal endocytosis and protease delivery to early endosomes in sporadic Alzheimer's disease: neuropathologic evidence for a mechanism of increased beta-amyloidogenesis. J Neurosci 17:6142-6151. Medline

Cataldo AM, Peterhoff CM, Troncoso JC, Gomez-Isla T, Hyman BT, Nixon RA (2000) Endocytic pathway abnormalities precede amyloid beta deposition in sporadic Alzheimer's disease and Down syndrome: differential effects of APOE genotype and presenilin mutations. Am J Pathol 157:277-286. CrossRef Medline

Cataldo AM, Petanceska S, Terio NB, Peterhoff CM, Durham R, Mercken M, Mehta PD, Buxbaum J, Haroutunian V, Nixon RA (2004) Abeta localization in abnormal endosomes: association with earliest Abeta elevations in AD and Down syndrome. Neurobiol Aging 25:1263-1272. CrossRef Medline

Kooner JS, Saleheen D, Sim X, Sehmi J, Zhang W, Frossard P, Been LF, Chia KS, Dimas AS, Hassanali N, Jafar T, Jowett JB, Li X, Radha V, Rees SD, Takeuchi F, Young R, Aung T, Basit A, Chidambaram M, et al. (2011) Genome-wide association study in individuals of South Asian ancestry identifies six new type 2 diabetes susceptibility loci. Nat Genet 43:984989. CrossRef Medline

Chen ZY, Ieraci A, Teng H, Dall H, Meng CX, Herrera DG, Nykjaer A, Hempstead BL, Lee FS (2005) Sortilin controls intracellular sorting of brainderived neurotrophic factor to the regulated secretory pathway. J Neurosci 25:6156-6166. CrossRef Medline

Choy RW, Cheng Z, Schekman R (2012) Amyloid precursor protein (APP) 
traffics from the cell surface via endosomes for amyloid beta (Abeta) production in the trans-Golgi network. Proc Natl Acad Sci U S A 109: E2077-E2082. CrossRef Medline

Clee SM, Yandell BS, Schueler KM, Rabaglia ME, Richards OC, Raines SM, Kabara EA, Klass DM, Mui ET, Stapleton DS, Gray-Keller MP, Young MB, Stoehr JP, Lan H, Boronenkov I, Raess PW, Flowers MT, Attie AD (2006) Positional cloning of Sorcs1, a type 2 diabetes quantitative trait locus. Nat Genet 38:688-693. CrossRef Medline

Deinhardt K, Salinas S, Verastegui C, Watson R, Worth D, Hanrahan S, Bucci C, Schiavo G (2006) Rab5 and Rab7 control endocytic sorting along the axonal retrograde transport pathway. Neuron 52:293-305. CrossRef Medline

Deinhardt K, Kim T, Spellman DS, Mains RE, Eipper BA, Neubert TA, Chao MV, Hempstead BL (2011) Neuronal growth cone retraction relies on proneurotrophin receptor signaling through Rac. Sci Signal 4:ra82. CrossRef Medline

Dodson SE, Gearing M, Lippa CF, Montine TJ, Levey AI, Lah JJ (2006) LR11/SorLA expression is reduced in sporadic Alzheimer disease but not in familial Alzheimer disease. J Neuropathol Exp Neurol 65:866-872. CrossRef Medline

Dubé JB, Johansen CT, Hegele RA (2011) Sortilin: an unusual suspect in cholesterol metabolism: from GWAS identification to in vivo biochemical analyses, sortilin has been identified as a novel mediator of human lipoprotein metabolism. Bioessays 33:430-437. CrossRef Medline

Evans SF, Irmady K, Ostrow K, Kim T, Nykjaer A, Saftig P, Blobel C, Hempstead BL (2011) Neuronal brain-derived neurotrophic factor is synthesized in excess, with levels regulated by sortilin-mediated trafficking and lysosomal degradation. J Biol Chem 286:29556-29567. CrossRef Medline

Finan GM, Okada H, Kim TW (2011) BACE1 retrograde trafficking is uniquely regulated by the cytoplasmic domain of sortilin. J Biol Chem 286:12602-12616. CrossRef Medline

Fjorback AW, Seaman M, Gustafsen C, Mehmedbasic A, Gokool S, Wu C, Militz D, Schmidt V, Madsen P, Nyengaard JR, Willnow TE, Christensen EI, Mobley WB, Nykjær A, Andersen OM (2012) Retromer binds the FANSHY sorting motif in SorLA to regulate amyloid precursor protein sorting and processing. J Neurosci 32:1467-1480. CrossRef Medline

Goodarzi MO, Lehman DM, Taylor KD, Guo X, Cui J, Quiñones MJ, Clee SM, Yandell BS, Blangero J, Hsueh WA, Attie AD, Stern MP, Rotter JI (2007) SORCS1: a novel human type 2 diabetes susceptibility gene suggested by the mouse. Diabetes 56:1922-1929. CrossRef Medline

Granhall C, Park HB, Fakhrai-Rad H, Luthman H (2006) High-resolution quantitative trait locus analysis reveals multiple diabetes susceptibility loci mapped to intervals $<800 \mathrm{~kb}$ in the species-conserved Niddmli of the GK rat. Genetics 174:1565-1572. CrossRef Medline

Hermey G, Riedel IB, Rezgaoui M, Westergaard UB, Schaller C, HermansBorgmeyer I (2001) SorCS1, a member of the novel sorting receptor family, is localized in somata and dendrites of neurons throughout the murine brain. Neurosci Lett 313:83-87. CrossRef Medline

Hermey G, Plath N, Hübner CA, Kuhl D, Schaller HC, Hermans-Borgmeyer I (2004) The three sorCS genes are differentially expressed and regulated by synaptic activity. J Neurochem 88:1470-1476. CrossRef Medline

Hu F, Padukkavidana T, Vægter CB, Brady OA, Zheng Y, Mackenzie IR, Feldman HH, Nykjaer A, Strittmatter SM (2010) Sortilin-mediated endocytosis determines levels of the frontotemporal dementia protein, progranulin. Neuron 68:654-667. CrossRef Medline

Israel MA, Yuan SH, Bardy C, Reyna SM, Mu Y, Herrera C, Hefferan MP, Van Gorp S, Nazor KL, Boscolo FS, Carson CT, Laurent LC, Marsala M, Gage FH, Remes AM, Koo EH, Goldstein LS (2012) Probing sporadic and familial Alzheimer's disease using induced pluripotent stem cells. Nature 482:216-220. Medline

Jacobsen L, Madsen P, Jacobsen C, Nielsen MS, Gliemann J, Petersen CM (2001) Activation and functional characterization of the mosaic receptor SorLA/LR11. J Biol Chem 276:22788-22796. CrossRef Medline

Jedrychowski MP, Gartner CA, Gygi SP, Zhou L, Herz J, Kandror KV, Pilch PF (2010) Proteomic analysis of GLUT4 storage vesicles reveals LRP1 to be an important vesicle component and target of insulin signaling. J Biol Chem 285:104-114. CrossRef Medline

Kooner JS, Saleheen D, Sim X, Sehmi J, Zhang W, Frossard P, Been LF, Chia KS, Dimas AS, Hassanali N, Jafar T, Jowett JB, Li X, Radha V, Rees SD, Takeuchi F, Young R, Aung T, Basit A, Chidambaram M, et al. (2011) Genome-wide association study in individuals of South Asian ancestry identifies six new type 2 diabetes susceptibility loci. Nat Genet 43:984989. CrossRef Medline

Lane RF, Raines SM, Steele JW, Ehrlich ME, Lah JA, Small SA, Tanzi RE, Attie AD, Gandy S (2010) Diabetes-associated SorCS1 regulates Alzheimer's amyloid-beta metabolism: evidence for involvement of SorL1 and the retromer complex. J Neurosci 30:13110-13115. CrossRef Medline

Lao A, Schmidt V, Schmitz Y, Willnow TE, Wolkenhauer O (2012) Multicompartmental modeling of SORLA's influence on amyloidogenic processing in Alzheimer's disease. BMC Syst Biol 6:74. Medline

Liang X, Slifer M, Martin ER, Schnetz-Boutaud N, Bartlett J, Anderson B, Züchner S, Gwirtsman H, Gilbert JR, Pericak-Vance MA, Haines JL (2009) Genomic convergence to identify candidate genes for Alzheimer disease on chromosome 10. Hum Mutat 30:463-471. CrossRef Medline

Mufson EJ, Wuu J, Counts SE, Nykjaer A (2010) Preservation of cortical sortilin protein levels in MCI and Alzheimer's disease. Neurosci Lett 471: 129-133. CrossRef Medline

Muhammad A, Flores I, Zhang H, Yu R, Staniszewski A, Planel E, Herman M, Ho L, Kreber R, Honig LS, Ganetzky B, Duff K, Arancio O, Small SA (2008) Retromer deficiency observed in Alzheimer's disease causes hippocampal dysfunction, neurodegeneration, and Abeta accumulation. Proc Natl Acad Sci U S A 105:7327-7332. CrossRef Medline

Musunuru K, Strong A, Frank-Kamenetsky M, Lee NE, Ahfeldt T, Sachs KV, Li X, Li H, Kuperwasser N, Ruda VM, Pirruccello JP, Muchmore B, Prokunina-Olsson L, Hall JL, Schadt EE, Morales CR, Lund-Katz S, Phillips MC, Wong J, Cantley W, et al. (2010) From noncoding variant to phenotype via SORT1 at the 1p13 cholesterol locus. Nature 466:714-719. CrossRef Medline

Nielsen MS, Madsen P, Christensen EI, Nykjaer A, Gliemann J, Kasper D, Pohlmann R, Petersen CM (2001) The sortilin cytoplasmic tail conveys Golgi-endosome transport and binds the VHS domain of the GGA2 sorting protein. EMBO J 20:2180-2190. CrossRef Medline

Nykjaer A, Willnow TE (2012) Sortilin: a receptor to regulate neuronal viability and function. Trends Neurosci 35:261-270. CrossRef Medline

Offe K, Dodson SE, Shoemaker JT, Fritz JJ, Gearing M, Levey AI, Lah JJ (2006) The lipoprotein receptor LR11 regulates amyloid beta production and amyloid precursor protein traffic in endosomal compartments. J Neurosci 26:1596-1603. CrossRef Medline

Ott A, Stolk RP, Hofman A, van Harskamp F, Grobbee DE, Breteler MM (1996) Association of diabetes mellitus and dementia: the Rotterdam Study. Diabetologia 39:1392-1397. CrossRef Medline

Paterson AD, Waggott D, Boright AP, Hosseini SM, Shen E, Sylvestre MP, Wong I, Bharaj B, Cleary PA, Lachin JM, Below JE, Nicolae D, Cox NJ, Canty AJ, Sun L, Bull SB (2010) A genome-wide association study identifies a novel major locus for glycemic control in type 1 diabetes, as measured by both A1C and glucose. Diabetes 59:539-549. CrossRef Medline

Pottier C, Hannequin D, Coutant S, Rovelet-Lecrux A, Wallon D, Rousseau S, Legallic S, Paquet C, Bombois S, Pariente J, Thomas-Anterion C, Michon A, Croisile B, Etcharry-Bouyx F, Berr C, Dartigues JF, Amouyel P, Dauchel H, Boutoleau-Bretonnière C, Thauvin C, et al. (2012) High frequency of potentially pathogenic SORL1 mutations in autosomal dominant early-onset Alzheimer disease. Mol Psychiatry 17:875-879. CrossRef Medline

Qiang L, Fujita R, Yamashita T, Angulo S, Rhinn H, Rhee D, Doege C, Chau L, Aubry L, Vanti WB, Moreno H, Abeliovich A (2011) Directed conversion of Alzheimer's disease patient skin fibroblasts into functional neurons Cell 146:359-371. CrossRef

Reitz C, Cheng R, Rogaeva E, Lee JH, Tokuhiro S, Zou F, Bettens K, Sleegers K, Tan EK, Kimura R, Shibata N, Arai H, Kamboh MI, Prince JA, Maier W, Riemenschneider M, Owen M, Harold D, Hollingworth P, Cellini E, et al. (2011a) Meta-analysis of the association between variants in SORL1 and Alzheimer disease. Arch Neurol 68:99-106. CrossRef Medline

Reitz C, Lee JH, Rogers RS, Mayeux R (2011b) Impact of genetic variation in SORCS1 on memory retention. PLoS One 6:e24588. CrossRef Medline

Reitz C, Tokuhiro S, Clark LN, Conrad C, Vonsattel JP, Hazrati LN, Palotás A, Lantigua R, Medrano M, Jiménez-Velázquez Z, Vardarajan B, Simkin I, Haines JL, Pericak-Vance MA, Farrer LA, Lee JH, Rogaeva E, GeorgeHyslop PS, Mayeux R (2011c) SORCS1 alters amyloid precursor protein processing and variants may increase Alzheimer's disease risk. Ann Neurol 69:47-64. CrossRef Medline

Rogaeva E, Meng Y, Lee JH, Gu Y, Kawarai T, Zou F, Katayama T, Baldwin CT, Cheng R, Hasegawa H, Chen F, Shibata N, Lunetta KL, PardossiPiquard R, Bohm C, Wakutani Y, Cupples LA, Cuenco KT, Green RC, 
Pinessi L, et al. (2007) The neuronal sortilin-related receptor SORL1 is genetically associated with Alzheimer disease. Nat Genet 39:168-177. CrossRef Medline

Sager KL, Wuu J, Leurgans SE, Rees HD, Gearing M, Mufson EJ, Levey AI, Lah JJ (2007) Neuronal LR11/sorLA expression is reduced in mild cognitive impairment. Ann Neurol 62:640-647. CrossRef Medline

Schmidt V, Sporbert A, Rohe M, Reimer T, Rehm A, Andersen OM, Willnow TE (2007) SorLA/LR11 regulates processing of amyloid precursor protein via interaction with adaptors GGA and PACS-1. J Biol Chem 282: 32956-32964. CrossRef Medline

Schmidt V, Baum K, Lao A, Rateitschak K, Schmitz Y, Teichmann A, Wiesner B, Petersen CM, Nykjaer A, Wolf J, Wolkenhauer O, Willnow TE (2012) Quantitative modelling of amyloidogenic processing and its influence by SORLA in Alzheimer's disease. EMBO J 31:187-200. Medline

Small SA (2008) Retromer sorting: a pathogenic pathway in late-onset Alzheimer disease. Arch Neurol 65:323-328. CrossRef Medline

Small SA, Gandy S (2006) Sorting through the cell biology of Alzheimer's disease: intracellular pathways to pathogenesis. Neuron 52:15-31. CrossRef Medline

Small SA, Kent K, Pierce A, Leung C, Kang MS, Okada H, Honig L, Vonsattel JP, Kim TW (2005) Model-guided microarray implicates the retromer complex in Alzheimer's disease. Ann Neurol 58:909-919. CrossRef Medline

Sullivan CP, Jay AG, Stack EC, Pakaluk M, Wadlinger E, Fine RE, Wells JM, Morin PJ (2011) Retromer disruption promotes amyloidogenic APP processing. Neurobiol Dis 43:338 -345. CrossRef Medline

Teng KK, Felice S, Kim T, Hempstead BL (2010) Understanding proneurotrophin actions: recent advances and challenges. Dev Neurobiol 70: 350-359. Medline

Vaegter CB, Jansen P, Fjorback AW, Glerup S, Skeldal S, Kjolby M, Richner M, Erdmann B, Nyengaard JR, Tessarollo L, Lewin GR, Willnow TE, Chao MV, Nykjaer A (2011) Sortilin associates with Trk receptors to enhance anterograde transport and neurotrophin signaling. Nat Neurosci 14: 54-61. CrossRef Medline
Vardarajan BN, Bruesegem SY, Harbour ME, George-Hyslop PS, Seaman MN, Farrer LA (2012) Identification of Alzheimer disease-associated variants in genes that regulate retromer function. Neurobiol Aging 33:2231.e15-2231.e30.

Vassilopoulos S, Esk C, Hoshino S, Funke BH, Chen CY, Plocik AM, Wright WE, Kucherlapati R, Brodsky FM (2009) A role for the CHC22 clathrin heavy-chain isoform in human glucose metabolism. Science 324:11921196. CrossRef Medline

Vieira SI, Rebelo S, Esselmann H, Wiltfang J, Lah J, Lane R, Small SA, Gandy S, da Cruz e Silva EF, da Cruz e Silva OA (2010) Retrieval of the Alzheimer's amyloid precursor protein from the endosome to the TGN is S655 phosphorylation state-dependent and retromer-mediated. Mol Neurodegener 5:40. CrossRef Medline

Vilariño-Güell C, Wider C, Ross OA, Dachsel JC, Kachergus JM, Lincoln SJ, Soto-Ortolaza AI, Cobb SA, Wilhoite GJ, Bacon JA, Behrouz B, Melrose HL, Hentati E, Puschmann A, Evans DM, Conibear E, Wasserman WW, Aasly JO, Burkhard PR, Djaldetti R, et al. (2011) VPS35 mutations in Parkinson disease. Am J Hum Genet 89:162-167. CrossRef Medline

Wang HF, Yu JT, Zhang W, Wang W, Liu QY, Ma XY, Ding HM, Tan L (2012) SORCS1 and APOE polymorphisms interact to confer risk for late-onset Alzheimer's disease in a Northern Han Chinese population. Brain Res 1448:111-116. CrossRef Medline

Willnow TE, Carlo AS, Rohe M, Schmidt V (2010) SORLA/SORL1, a neuronal sorting receptor implicated in Alzheimer's disease. Rev Neurosci 21:315-329. CrossRef Medline

Willnow TE, Kjølby M, Nykjaer A (2011) Sortilins: new players in lipoprotein metabolism. Curr Opin Lipidol 22:79-85. CrossRef Medline

Zimprich A, Benet-Pagès A, Struhal W, Graf E, Eck SH, Offman MN, Haubenberger D, Spielberger S, Schulte EC, Lichtner P, Rossle SC, Klopp N, Wolf E, Seppi K, Pirker W, Presslauer S, Mollenhauer B, Katzenschlager R, Foki T, Hotzy C, et al. (2011) A mutation in VPS35, encoding a subunit of the retromer complex, causes late-onset Parkinson disease. Am J Hum Genet 89:168-175. CrossRef Medline 